
\title{
㗈 New Disease Reports \\ First report of Tomato leaf curl New Delhi virus and the whitefly Bemisia tabaci Asial species on tomato in the Seychelles
}

\author{
S. Scussel ${ }^{1}$, S. Claverie ${ }^{1}$, M. Hoareau ${ }^{1}$, C. Simiand ${ }^{1}$, B. Reynaud ${ }^{1}$, R. Moustache ${ }^{2}$, P. Lefeuvre ${ }^{1}$, H. Delatte ${ }^{1}$ and J.M. Lett $^{1 *}$
}

${ }^{1}$ CIRAD, UMR PVBMT, Pôle de Protection des Plantes, 97410 Saint-Pierre, lle de La Réunion, France; ${ }^{2}$ National Biosecurity Agency, P.O. Box 464, Bel Air Complex, Revolution Avenue Victoria, Republic of Seychelles

*E-mail: lett@cirad.fr

Received: 23 Aug 2018. Published: 14 Sep 2018. Keywords: Begomovirus, Geminiviridae, surveillance, tomato leaf curl disease

In July 2017, severe symptoms of leaf curling resembling those of tomato leaf curl disease and outbreaks of whiteflies (more than 50 individuals per plant) were observed on tomato (Solanum lycopersicum) plants in open fields and in greenhouses on the island of Praslin in the Seychelles (Fig. 1). Symptomatic tomato leaf samples and whiteflies were collected (Table 1).

Three tomato leaf samples were tested for the presence of begomoviruses using PCR assays with a set of degenerate primers designed to amplify the coat protein gene of the Old World begomovirus DNA-A component (Clust4CP-F342/Clust4CP-R1032; Séka et al., 2016). PCR products of the expected size were obtained from one sample, suggesting the presence of an Old World begomovirus. To characterise the complete genome, DNA-A and -B molecules were amplified by rolling-circle amplification, cloned using $E c o$ RV and $P s t I$ restriction enzymes and sequenced. BLASTn analysis showed that the DNA-A sequence (2,740 nucleotides; GenBank Accession No. MH511991) shared the highest nucleotide identity (99\%) with potato isolates of Tomato leaf curl New Delhi virus (ToLCNDV; KC874503 and AY286316) from India. The DNA-B sequence (2,695 nucleotides; MH511990) shared the highest nucleotide sequence identity (99\%) with a potato isolate of Tomato leaf curl New Delhi virus (ToLCNDV; FN356024) also from India. Maximum-likelihood phylogenetic trees constructed with publicly available begomovirus sequences (MEGA6; Tamura et al., 2013), confirmed the genetic relationship of the Seychelles isolate of ToLCNDV with isolates from India (Fig. 2). PCR diagnosis performed with specific primers designed to amplify the coat protein ORF of ToLCNDV DNA-A and direct sequencing of amplicons confirmed the presence and the identity of ToLCNDV in two tomato samples from two different plots (Table 1). In parallel, total DNA was extracted from 20 female whiteflies (Table 1), to identify their species. The core region of the mitochondrial cytochrome oxidase I gene was amplified and sequenced with the general primer set C1-J-2195 and L2-N-3014 (Simon et al., 1994). Sequences 755 bp in length were obtained. A single haplotype was retrieved and showed $100 \%$ pairwise sequence identity (BLASTn) with Thai isolates of Asial $B$. tabaci species (KR110108).

To our knowledge, this is the first report of the bipartite Old World ToLCNDV associated with leaf curl disease on tomato in the Seychelles and more widely in sub-Saharan Africa. Despite a viral description based on a small number of symptomatic tomato samples from the same locality and the lack of information regarding the outbreak and natural occurrence of ToLCNDV on tomato crops in the Seychelles, this description confirms
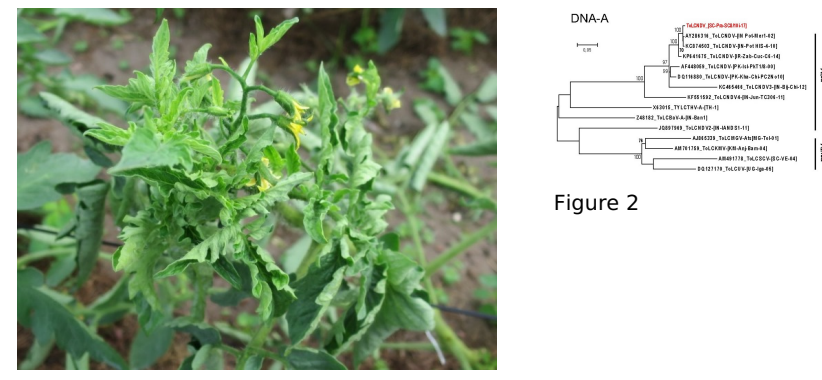

Figure 2 the spread of ToLCNDV outside the Indian sub-continent. The concomitant description of ToLCNDV and B. tabaci Asial species in the Seychelles is consistent with the fact that both are considered native to Asia (Moriones et al., 2017, and Rekha et al., 2005; respectively). This report is of prime importance for regional management of emerging diseases on vegetable crops since ToLCNDV causes diseases in a large number of plant species belonging to different families including the Cucurbitaceae, Fabaceae, Malvaceae and Solanaceae (Moriones et al., 2017).

\section{Acknowledgements}

This study was funded by the European Union (ERDF, INTERREGV), the Conseil Régional de La Réunion and CIRAD, and conducted on the Plant Protection Platform (3P, IBISA). The authors thank Roy Govinden and Samuel Brutus for their excellent technical assistance during the survey.

\section{References}

Moriones E, Praveen S, Chakraborty S, 2017. Tomato leaf curl New Delhi virus: An emerging virus complex threatening vegetable and fiber crops. Viruses 9, 264. http://dx.doi.org/10.3390/v9100264

Rekha AR, Maruthi MN, Muniyappa V, Colvin J, 2005. Occurrence of three genotypic clusters of Bemisia tabaci and the rapid spread of the B biotype in south India. Entomologia Experimentalis et Applicata. 117, 221-233. http://dx.doi.org/10.1111/j.1570-7458.2005.00352.x

Séka K, Ouattara A, Assiri KP, Kra KD, Hoareau M, Lefeuvre P, Diallo HA, Lett JM, 2016. First report of Cotton leaf curl Gezira virus and Okra yellow crinkle virus associated with okra leaf curl disease in Côte d'Ivoire. New Disease Reports 34, 8 .

http://dx.doi.org/10.5197/j.2044-0588.2016.034.008

Simon C, Frati F, Beckenbach A, Crespi B, Liu H, Flook P, 1994 Evolution, weighting, and phylogenetic utility of mitochondrial gene sequences and a compilation of conserved polymerase chain reaction primers. Annals of the Entomological Society of America 87, 651-701. http://dx.doi.org/10.1093/aesa/87.6.651

Tamura K, Peterson D, Peterson N, Stecher G, Nei M, Kumar S, 2011. MEGA5: Molecular evolutionary genetics analysis using maximum likelihood, evolutionary distance, and maximum parsimony methods. Molecular Biology and Evolution 28, 2731-2739.

http://dx.doi.org/10.1093/molbev/msr121

Figure 1

To cite this report: Scussel S, Claverie S, Hoareau M, Simiand C, Reynaud B, Moustache R, Lefeuvre P, Delatte H, Lett JM, 2018. First report of Tomato leaf curl New Delhi virus and the whitefly Bemisia tabaci Asial species on tomato in the Seychelles. New Disease Reports 38, 2. http://dx.doi.org/10.5197/j.2044-0588.2018.038.002 